DOI: 10.1515/auseur-2017-0006

\title{
The Development Path of the Miskolc Agglomeration (1970-2015)
}

\author{
Andrea KRISTÓF \\ University of Nyíregyháza, Institute of Tourism and Geography \\ e-mail: kristof.andrea@nye.hu
}

\begin{abstract}
The historical development of the socio-economic, environmental effects of the agglomerating process in the region of Miskolc has remained an unexplored area. The economic crisis and the signs of crisis present in the Miskolc agglomeration too have changed the attitudes of settlements towards agglomerating and suburbanizing processes. These changes also affect the suburbanizing processes in the Miskolc agglomeration, i.e. the intensity of suburbanization is decreasing. The suburbs of Miskolc have become more fragmented and polarized in terms of the society and economy. The geographical separation of high- and low-status suburbs proves the ever-increasing segregation within the metropolitan area.
\end{abstract}

Keywords: suburbanization, suburbs of Miskolc, agglomeration, segregation, metropolitan area

\section{Introduction}

Most studies dealing with the socio-economic changes in the agglomerations of Hungary are primarily concerned with Budapest and its surroundings as well as with large cities (e.g. Győr, Pécs, etc.) and their neighbourhoods most strongly affected by dynamic economic growth. Hungarian geographers define differently the agglomerations of Hungarian cities in time and space; moreover, the special set of concepts used by different branches of science also results in different interpretations (e.g. Tímár 2006, Nagy-Tímár 2010, etc.). One of the biggest shortcomings of research produced over the past half century is that it has not explored properly the historical stages and characteristics of the agglomerating process in the Miskolc metropolitan area. With respect to the historical background, it is important to emphasize that the development of agglomerations in Hungary was not a sudden moment but rather a long development path (Tóth 2006). One of the basic tasks of the historical research of agglomerations today is 
still to interpret this development path and examine those factors that have led to the development of agglomerations and determined their evolution.

There is no consensus among scientists regarding the starting date, dynamics, and stages of development of the agglomerating process around Miskolc (e.g. Tóth 2004, 2006; Kőszegfalvi 2006, Kovács 2003, etc.). The reasons behind this may include the different interpretations of the extensive (e.g. population growth, housing construction, the establishment of the basic infrastructure network) and the intensive stages (a contiguous, physically integrated area of settlements is created, and formerly autonomous settlements may merge together; the system of linear infrastructure intertwines and integrates the whole area of the agglomeration, etc.) of the agglomerating process. The different pieces of research so far have focused on a specific point in time and have not dealt with the changes of factors in time that resulted in agglomerating processes and the changes in the geographical extension of the Miskolc agglomeration.

The aim of my study is to present how the socio-economic development (from simple migration to intensive agglomerating processes) of the past half century has affected Miskolc and the settlements located within its narrower socioeconomic neighbourhood as well as the changes in vertical relationships and the horizontal extension of this settlement group (defined as agglomeration since 1970). This process has resulted in the restructuring of the agglomeration around Miskolc in two phases and in the social, demographic, economic, and functional differentiation of settlements.

\section{Formation of the Miskolc Agglomeration}

Miskolc lies at the meeting point of the Bükk Mountains and the Cserehát (the Miskolc Gate and its broader surroundings), and geographical energies, economic geographical position, and urban structure have always determined local people's living environment. From the second half of the $19^{\text {th }}$ century, the development of the city accelerated and from the 1880s it became the centre of one of the fastest developing heavy industrial regions of historical Hungary. The city's population increased almost two and a half times between 1870 and 1910, and the surrounding settlements - which were formerly autonomous, but now they are part of Miskolc - also showed similar population dynamics (Table 1). The explosive population growth strongly correlated with the development of heavy industry. 
Table 1. Population change in settlements attached to 'Greater Miskolc' (18701949)

\begin{tabular}{lllllll}
\hline Settlements & $\mathbf{1 8 7 0}$ & $\mathbf{1 8 8 0}$ & $\mathbf{1 9 1 0}$ & $\mathbf{1 9 3 0}$ & $\mathbf{1 9 4 1}$ & $\mathbf{1 9 4 9}$ \\
\hline Miskolc & 21,535 & 24,319 & 49,182 & 61,559 & 77,362 & 103,690 \\
\hline Diósgyőr & 4,312 & 4,630 & 17,204 & 20,854 & 26,539 & N/A \\
\hline $\begin{array}{l}\text { of which: Vasgyár and } \\
\text { Ujjdiósgyőr }\end{array}$ & N/A & approx. 2,000 & 7,771 & $\begin{array}{l}6,187 \\
+3,479\end{array}$ & $\begin{array}{l}6,886 \\
+2,452\end{array}$ & N/A \\
\hline Pereces & N/A & N/A & 2,312 & 3,007 & 2,902 & N/A \\
\hline Görömböly & 1,175 & 1,160 & 1,840 & 2,296 & 2,845 & 2,177 \\
\hline Hejőcsaba & 1,542 & 1,570 & 3,184 & 6,356 & 5,036 & N/A \\
\hline of which: Martintelep & N/A & N/A & 493 & 1,935 & 1,331 & N/A \\
\hline Hámor & 1,011 & 827 & 978 & 1,053 & 1,030 & 1,321 \\
\hline Szirma & 1,114 & 1,163 & 1,545 & 1,794 & 1,899 & 1,958 \\
\hline Total & $\mathbf{3 0 , 6 8 9}$ & $\mathbf{3 3 , 6 6 9}$ & $\mathbf{7 3 , 9 3 3}$ & $\mathbf{9 3 , 9 1 2}$ & $\mathbf{1 1 4 , 7 1 1}$ & $\mathbf{1 0 9 , 1 4 6}$ \\
\hline
\end{tabular}

Source: edited by the author according to census data (1870-1949)

The role and position of Miskolc, whose relationships with settlements in southern Borsod were intensifying, fundamentally changed with the Treaty of Trianon. Before the Treaty of Trianon, Miskolc was the $12^{\text {th }}$ most populous city in historical Hungary, whereas after the treaty it became the $6^{\text {th }}$ one. Miskolc became the leading city (with no other competing cities such as Kosice) of the region, and it turned into the industrial, commercial, financial, and cultural centre of Northern Hungary.

Between the two world wars, the close relationships among Miskolc and the surrounding settlements were also reflected by the dynamic population growth. The population of the city together with that of Diósgyőr grew to over 100,000 as early as 1941 (Table 1), and it was only a matter of time before the functionally integrated settlements would be merged through law ('Greater Miskolc'). The idea of creating 'Greater Miskolc' occurred as early as at the turn of the $19^{\text {th }}$ and the $20^{\text {th }}$ centuries, but it became reality only in 1945, when Diósgyőr, Hejőcsaba, and Tapolca (which was separated from Görömböly) were attached to Miskolc. The area and population of 'Greater Miskolc' increased further in 1950, when Görömböly, Hámor, and Szirma were also attached to its area; thus Miskolc became the second largest city in Hungary (Table 1, Map 1).

At the dawn of the Second World War, the intensity and depth of the socio-economic relationships probably reached the level what is called today 'settlement group'. Partly due to special circumstances, the precursors of the Miskolc agglomeration should primarily be investigated in this settlement group. 


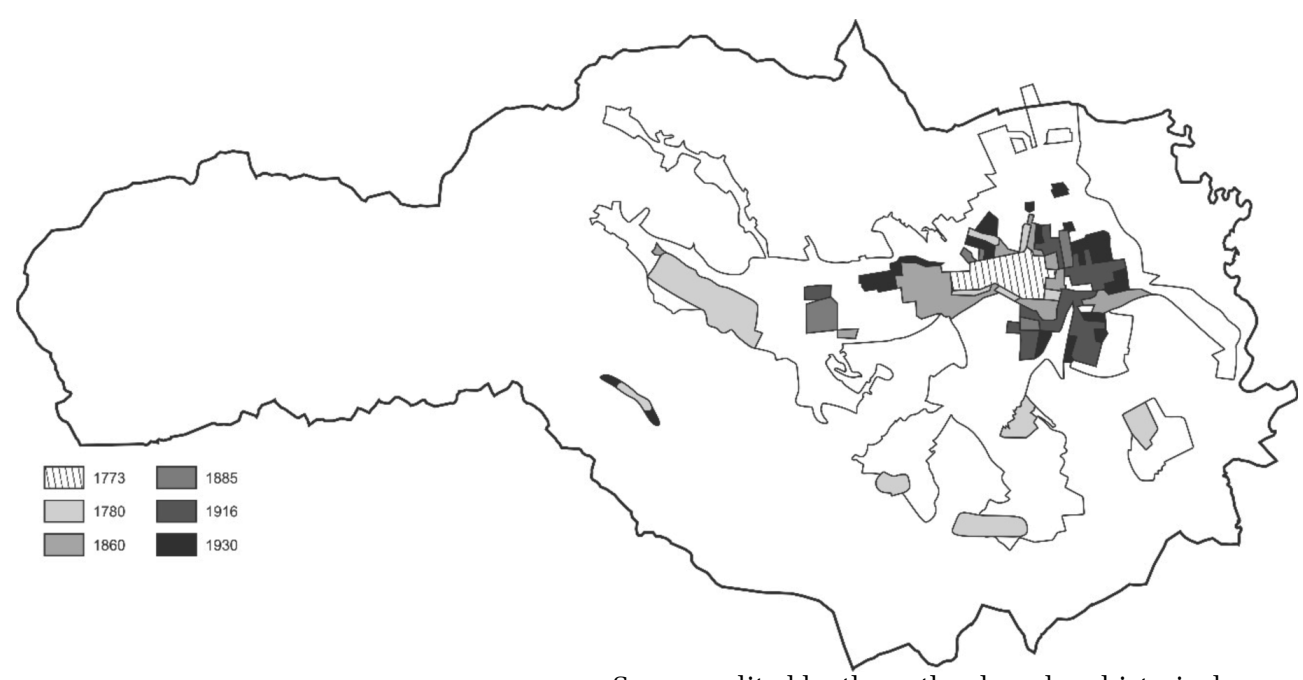

Source: edited by the author based on historical maps

Map 1. Territorial expansion of Miskolc, changes in built-up areas (1773-2015)

After the Second World War, the primary goal of the fundamentally altered settlement policy was to establish the conditions for socialist industrialization at the level of settlements, but at the same time industrialization was also one of the most important tools of settlement development. In this respect, the development of Miskolc was prioritized and the city also received distinguished political attention. Research on Hungarian settlement groups and agglomerations (e.g. Fórizs 1967, Perczel 1964, etc.) has shown that the concentration of socialist productive forces played the most important role in the formation of agglomerations. Margit Fórizs grouped 35 settlements into the Miskolc settlement group based on four factors (healthcare, secondary education, retailing, and industrial commuters). The most striking features of this process for researchers investigating the extent of agglomerating in Hungary were rapid population growth and extensive commuting, although the intensity of these factors (especially of the former one) has significantly decreased since the end of the 1980s. Besides the geographical concentration of industrial production, the population and infrastructure development also supported the formation of agglomerations (Kôszegfalvi 1979). When the proportion of industrial commuters was examined, it was found that in 1960 the number of commuters arriving in Miskolc was the second highest in Hungary after Budapest. At that time, the number of inbound commuters was 24,197 (24.6\%), which added to the number of local workers in Miskolc $(73,918)$, which means that there were almost 100,000 jobs in the second most populous city of Hungary (Table 2). Meanwhile, the number of inbound commuters in the case of other Hungarian cities with a population over 100,000 was under 10,000 (e.g. the number of inbound commuters was 8,896 in Pécs, 8,518 in Szeged, and 7,900 in Debrecen). 
Table 2. Inbound commuters in Miskolc in the percentage of active earners (1960)

\begin{tabular}{|c|c|c|c|c|c|c|c|}
\hline Settlements & Commuters & $\begin{array}{c}\text { Active } \\
\text { earners }\end{array}$ & $\%$ & Settlement & Commuters & $\begin{array}{c}\text { Active } \\
\text { earners }\end{array}$ & $\%$ \\
\hline Hejóbába & 519 & 768 & 67.6 & Szikszó & 790 & 3,072 & 25.7 \\
\hline Sajóbábony & 975 & 1,497 & 65.1 & Vatta & 140 & 552 & 25.4 \\
\hline Felsőzsolca & 1,026 & 1,695 & 60.5 & B.szt.lászló & 95 & 375 & 25.3 \\
\hline Szirmabesenyő & 710 & 1,454 & 48.8 & Taktaharkány & 448 & 1,790 & 25.0 \\
\hline Alsózsolca & 792 & 1,752 & 45.2 & Mályi & 195 & 796 & 24.5 \\
\hline Kistokaj & 225 & 500 & 45.0 & Emőd & 631 & 2,597 & 24.3 \\
\hline Nyékládháza & 567 & 1,353 & 41.9 & Gesztely & 226 & 942 & 24.0 \\
\hline Arnót & 188 & 492 & 38.2 & Ónod & 268 & 1,125 & 23.8 \\
\hline M.nyárád & 306 & 818 & 37.4 & Aszaló & 253 & 1,066 & 23.7 \\
\hline Onga & 571 & 1,607 & 35.5 & Sajópetri & 153 & 669 & 22.9 \\
\hline Tiszalúc & 658 & 1,860 & 35.4 & Sajóecseg & 86 & 446 & 19.3 \\
\hline Hejőkeresztúr & 159 & 451 & 35.3 & B.aranyos & 113 & 647 & 17.5 \\
\hline Sajókeresztúr & 187 & 589 & 31.7 & Taktaszada & 175 & 1,039 & 16.8 \\
\hline Berzék & 147 & 476 & 30.9 & M. keresztes & 467 & 2,785 & 16.8 \\
\hline Sajólád & 311 & 1,050 & 29.6 & Mezőkövesd & 1,620 & 9,670 & 16.8 \\
\hline Halmaj & 218 & 749 & 29.1 & F. dobsza & 111 & 800 & 13.9 \\
\hline Bőcs & 335 & 1,156 & 29.0 & Mezőcsát & 440 & 3,222 & 13.7 \\
\hline S.pálfala & 99 & 342 & 28.9 & Boldva & 120 & 987 & 12.2 \\
\hline B.szt.kereszt & 157 & 543 & 28.9 & B.ábrány & 114 & 938 & 12.2 \\
\hline Hernádnémeti & 448 & 1,588 & 28.2 & Sajóvámos & 124 & 1,221 & 10.2 \\
\hline Harsány & 266 & 970 & 27.4 & Szerencs & 251 & 4,054 & 6.2 \\
\hline Kisgyőr & 244 & 935 & 26.1 & Sajószt.péter & 224 & 5,073 & 4.4 \\
\hline
\end{tabular}

Source: edited by the author based on census data (1960)

The fact that more than 30 thousand $(30,479)$ people migrated to Miskolc between 1949 and 1960, which is the third highest number after Budapest (267,663 people) and Pécs (30,596 people), well illustrates the extent of the population concentration. The regional gravity intensity of Miskolc is shown by the fact that $48.3 \%$ of inmigrants arrived from the county (Borsod-Abaúj-Zemplén), 27.5\% arrived from neighbouring counties, $15.3 \%$ from other counties, and 8.9\% from Budapest.

The above data unambiguously suggest that by 1960 Miskolc had fulfilled the criteria for the first stage of the agglomerating process (developing functional relationships among settlements such as commuting between the place of residence and work), i.e. it is evident that Miskolc and the surrounding settlements together had become an agglomerating region. The basis for further development was created by the socialist socio-economic policy, which started in the 1960s and evolved in the 1970s (such as collectivization, industrial development, investments in infrastructure, etc.), as well as by political conditions (e.g. new economic mechanism etc.) and by the National Settlement Network Development Concept (1971). 


\section{The Development of the Miskolc Agglomeration (1970-1990)}

During the second stage of the agglomerating process, settlements interlock in space (Enyedi 1984, Tóth 1988, 2004) and later they coalesce (e.g. a common infrastructure network is established; a contiguous, physically integrated settlement area emerges, etc.). We can speak about an agglomeration when functional and spatial relationships are well established. In this respect, at the end of the 1970s, only the agglomerations of Budapest and Miskolc were regarded as fully developed in Hungary (Kőszegfalvi 1979, Süli-Zakar 1985, Tóth 1988).

Several pieces of research have been conducted on the agglomerative gravity intensity of Miskolc and the surrounding settlements, some of them (e.g. Koleszár 1980, Lukács-Perger 1975, Süli-Zakar 1985, etc.) focusing on a central issue (e.g. demographics, labour force commuting, retail gravity zones, etc.), while another group of researchers identified the area of the Miskolc agglomeration according to complex indicators (e.g. Szántó 1979, Süli-Zakar 1989, etc.).

Lukács and Perger (1975) identified the Miskolc agglomeration on the basis of 23 indicators (e.g. concentration of productive forces, population and supply of services, etc.). They grouped those settlements into the agglomeration whose indicators were the closest to those of Miskolc, used as a benchmark, while the minimum was represented by the average of the villages in Borsod-AbaújZemplén County. After the weighing of the indicators, they set up three categories (outer, middle, and inner zone) that simultaneously indicated gravity intensity.

Being an industrial centre, Miskolc concentrated a great number of productive forces, which was a fundamental prerequisite for the further development of the agglomeration. In the 1980s, there were not only future visions of the Miskolc agglomeration but also of the Miskolc-Sajó Valley agglomeration as well as of the Borsod heavy industrial agglomeration. The rapid development of Miskolc caused a significant extensive agglomerating process in the Sajó Valley, and close relationships were built among Miskolc and neighbouring settlements, including mining villages. As a result of this process, the occurrence of a polycentric settlement structure along the Ózd-Kazincbarcika-Miskolc-Leninváros heavy industrial axis was predicted. However, the significance of the heavy industrial companies was not an adequate condition for further development (e.g. heavy industrial companies employed approx. three-quarters of heavy industrial workers of Miskolc at the beginning of the 1980s; there were more than one hundred industrial sites in Miskolc in 1980, which made up for one third of all industrial sites in Borsod-Abaúj-Zemplén County). The extensive industrial growth of Miskolc was coupled with a geographical expansion as well (Map 1), many settlements being attached to the city between 1950 and 1981 (e.g. Lyukó, Bükkszentlászló, Garadna, Lillafüred, Pereces, Ó- and Újmassa, etc.); 
thus, Miskolc had become one of the largest (area: $224 \mathrm{~km}^{2}$ ) industrial cities of Hungary.

One of the most important tools for turning Miskolc into a socialist heavy industrial centre, which culminated at the middle of the 1980s, was the Lenin Steelworks, having more than 18,000 workers and more than 1 million tonnes of annual output. The population of the city reached its maximum at that time with more than 211,000 inhabitants. Miskolc's significant population growth, besides the natural increase, was due to the positive net migration rate and to the administratively enlarged urban area. The population of Miskolc was 181,398 in 1970 and 208,103 in 1980 (Table 3).

In the 1970s, the restructuring of the Hungarian settlement network also became more marked; different settlement structures evolved, and their development accelerated. According to Koleszár I. (1980), the gravity functions of Miskolc were wide-ranging, with one of the most significant gravity factors being undoubtedly the demand for labour. This is hardly disputable in the case of an industrial city like Miskolc, especially during the era of the 1960s and 1970s characterized by extensive industrialization and investments. The heaviest outmigration was characteristic of the villages in Abaúj-Torna and Zemplén, which had few arable lands, as well as of the settlements in the Borsod Plain, whose agricultural density used to be quite high previously.

Zs. Szántó (1979) showed that according to the investigation of the concentration of the productive forces by 45 factors, besides the Budapest agglomeration, the agglomerations of Pécs, Miskolc, and Lake Balaton as well as the agglomerating region of Komárom - moreover, potential agglomerations (e.g. Veszprém) and settlement groups (e.g. Nyíregyháza) - could be identified.

With regard to the above mentioned topic, it is important to mention that a significant dispute arose among Hungarian geographers on the developmental stages of settlement groups and agglomerations in the 1980s. In his 1985 paper, Professor József Tóth described this process in three stages: 'In our understanding, settlement groups, unified settlement groups, and agglomerations are elements of a developmental process caused by geographical concentration which is realized during urbanization. Further distinctions between different settlement structures can only be made on the basis of formal factors.'

Out of the 32 settlement formations in Hungary, György Kőszegfalvi (1979) classified 3 as agglomerations, 5 as agglomerating regions, 3 as urbanizing regions, 8 as small and 8 as large settlement groups surrounding cities, and 5 as twin or triad cities. The Hungarian Central Statistical Office (HCSO) officially identified settlement groups (for the first time, at the beginning of the 1980s) on the basis of Kőszegfalvi’s work (Pálné Kovács-Rechnitzer 1982). In 1985, the HCSO started to introduce settlement formations in Hungary and document their changes and development on the basis of approx. 40 selected data and indicators. 
The complex examination of the settlements of the Miskolc agglomeration was realized by cluster analysis at the beginning of the 1980s. Aggregate indicators were created for settlements surrounding Miskolc on the basis of demographics, the concentration of industrial productive forces and factors describing urbanization and infrastructure. Éva Valér (2010) explored the peculiarities and geographical changes of the process of agglomerating in Hungary between 1970 and 1990 through factor analysis of 30 socio-economic indicators. She showed that in the case of an agglomeration or an agglomerating region at least 5 out of the 30 indicators should be above the national average in at least 5 neighbouring settlements. In her opinion, the intensive migration towards cities and the preference for developing cities in the 1970s did not support agglomerating; thus, by 1980, the area and the functional spectrum of agglomerations had decreased in a number of regions. On the other hand, the 1980s were characterized by strengthening agglomerating tendencies. There was not only an increase in the number of settlements representing spatial concentration but also a spatial concentration within each settlement: moreover, the proportion of settlements representing high levels of spatial concentration also grew within each region. According to her, this process affected the Miskolc agglomeration as well since the number of settlements in this area was 33 in 1970 and 1980, while in 1990 there were already 55 settlements.

Signs of crisis, which destabilized the position and development of the socialist Hungarian economy, first appeared in the region of Miskolc at the beginning of the 1980s. These caused fundamental changes in the position and conditions for the development (or rather stagnation) of Miskolc and its agglomeration. The development path of planned co-centres (Kazincbarcika, Tiszaújváros) of the agglomeration deviated from Miskolc and the settlements around it. The number of settlements in the Miskolc agglomeration was first reduced to 17 and later to 13 (Table 3).

Table 3. The population of settlements in the Miskolc agglomeration (19492015)

\begin{tabular}{lrrrrrrrr}
\hline Settlements & $\mathbf{1 9 4 9}^{*}$ & $\mathbf{1 9 6 0}^{*}$ & $\mathbf{1 9 7 0}^{* *}$ & $\mathbf{1 9 8 0}^{* *}$ & $\mathbf{1 9 9 0}^{* *}$ & $\mathbf{2 0 0 1}^{* *}$ & $\mathbf{2 0 1 1}^{* *}$ & $\mathbf{2 0 1 5}^{* *}$ \\
\hline Miskolc & $\mathbf{1 0 9 , 8 4 1}^{*}$ & $\mathbf{1 4 4 , 7 4 1}$ & $\mathbf{1 8 1 , 3 9 8}$ & $\mathbf{2 0 8 , 1 0 3}$ & $\mathbf{1 9 6 , 4 4 2}$ & $\mathbf{1 8 4 , 1 2 5}$ & $\mathbf{1 6 7 , 7 5 4}^{\mathbf{1 5 9 , 5 5 4}}$ \\
\hline Alsózsolca & 3,093 & 3,819 & 5,116 & 5,590 & 5,723 & 6,044 & 5,766 & 5,683 \\
\hline Felsózsolca & 2,932 & 3,647 & 5,026 & 6,125 & 6,939 & 7,027 & 6,613 & 6,521 \\
\hline Onga & 2,515 & 3,070 & 3,456 & 3,616 & 4,042 & 4,761 & 4,858 & 4,746 \\
\hline Arnót & 894 & 962 & 1,143 & 1,560 & 2,082 & 2,557 & 2,597 & 2,420 \\
\hline Kistokaj & 839 & 1,044 & 1,157 & 1,245 & 1,489 & 1,868 & 2,078 & 2,084 \\
\hline Mályi & 1,138 & 1,690 & 2,080 & 2,500 & 3,353 & 4,152 & 4,124 & 4,016 \\
\hline Sajóbábony & 867 & 2697 & 3,117 & 3,416 & 3,291 & 3,137 & 2,887 & 2,786 \\
\hline Sajóecseg & 689 & 943 & 1,148 & 1,201 & 1,062 & 1,065 & 1,051 & 1,040 \\
\hline Sajókeresztúr & 818 & 1,285 & 1,462 & 1,520 & 1,506 & 1,513 & 1,549 & 1,483 \\
\hline Sajópálfala & 605 & 626 & 646 & 725 & 732 & 786 & 744 & 728 \\
\hline
\end{tabular}




\begin{tabular}{lrrrrrrrr}
\hline Settlements & $\mathbf{1 9 4 9}^{*}$ & $\mathbf{1 9 6 0}^{*}$ & $\mathbf{1 9 7 0}^{* *}$ & $\mathbf{1 9 8 0}^{* *}$ & $\mathbf{1 9 9 0}^{* *}$ & $\mathbf{2 0 0 1} * *$ & $\mathbf{2 0 1 1}^{* *}$ & $\mathbf{2 0 1 5}^{* *}$ \\
\hline Sajóvámos & 1,856 & 1,944 & 2,084 & 2,201 & 2,171 & 2,227 & 2,185 & 2,122 \\
\hline Szirmabesenyő & 2,589 & 3,210 & 4,347 & 4,769 & 4,836 & 4,729 & 4,438 & 4,181 \\
\hline Total & $\mathbf{1 8 , 8 3 5}$ & $\mathbf{2 4 , 9 3 7}$ & $\mathbf{3 0 , 7 8 2}$ & $\mathbf{3 4 , 4 6 8}$ & $\mathbf{3 7 , 2 2 6}$ & $\mathbf{3 9 , 8 6 6}$ & $\mathbf{3 8 , 8 9 0}$ & $\mathbf{3 7 , 8 1 0}$ \\
\hline Miskolc district & $\mathbf{1 6 4 , 7 8 5}$ & $\mathbf{2 0 9 , 3 7 3}$ & $\mathbf{2 5 2 , 6 1 3}$ & $\mathbf{2 8 3 , 8 7 8}$ & $\mathbf{2 7 4 , 9 5 3}$ & $\mathbf{2 6 8 , 4 3 7}$ & $\mathbf{2 5 0 , 5 3 0}$ & $\mathbf{2 4 0 , 2 7 9}$ \\
\hline & & & & & & & & \\
* present population & & & & & & &
\end{tabular}

During the examination of expected labour conditions in the region of Miskolc, István Süli-Zakar showed that the economy of the Miskolc agglomeration was not without its problems (e.g. the $80-90 \%$ share of the heavy industry, the one-sided sectoral structure of industrial workers, the negative net migration rate partly due to the previous fact, etc.). The economic difficulties of the basic sectors of the industry were already reflected in the demographics of the Miskolc agglomeration. Süli-Zakar identified an agglomeration of 14-15 settlements in the inner zone of the agglomerating region around Miskolc as the strongest economic centre. He anticipated that it would be especially hard to achieve a balance between the economy and the settlement network due to the sluggish economic restructuring and to population decline. He envisioned that the so-called 'unemployment inside the factory gate' would not be sustainable over the long term. According to Süli-Zakar, the development of services in the region were hampered by the lack of capital (while other sectors would not be able to employ the workforce that was not needed in the industry any more), which might result in the rapid population decline of the Borsod industrial region and the Miskolc agglomeration as well as in the slowdown of the agglomerating process (Süli-Zakar 1989).

\section{Suburbanization in the Miskolc Agglomeration (1990-2015)}

Suburbanization was detectable in all Hungarian urban regions from the beginning of the 1990s, and the changes occurring due to this process (e.g. population decline in the core cities, population increase in the suburban zone, boom in the housing market, appearance of gated communities, etc.) were fundamentally different from the former characteristics of agglomerating (e.g. Barta-Beluszky 1999, Dövényi-Kovács 1999, Tímár-Váradi 2000, etc.). Out of the Hungarian urban regions, in my previous studies (Kristóf 2013, 2014, 2015), I examined and explored in detail the suburbanization and its consequences as well as its special determining factors in the Miskolc agglomeration. Based on statistics, in this paper, I outline the most important socio-economic characteristics of the past 25 years (1990-2015) of suburbanization in the Miskolc agglomeration. In this framework, I have examined the changes in the demographics and some 
social factors of the agglomeration as well as migration trends determining suburbanization. Examination of the Miskolc suburbia from this point of view is important because both statistics and empirical studies show that the new socio-economic processes have reached the Miskolc agglomeration too and are characterized by special features (Table 4).

\section{IV.1. Changes in Population}

The Miskolc agglomeration is the largest population concentration in BorsodAbaúj-Zemplén County. It accounts for $13.8 \%$ of the area and $36.7 \%$ of the population of the county, which means that 251,901 people lived in the core city of the agglomeration and in the 35 settlements belonging to it as of 1 January 2015. The city and its agglomeration have been characterized so far by different demographical tendencies. The population of Miskolc has been continuously declining for three and a half decades, while the population of the suburbs grew dynamically until 2005; however, since then, a differential decline has been observable (Table 4). The general demographic state of the settlements is well represented by the fact that in the past ten years there has been an increase in the population of only three suburban settlements (Kistokaj, Kisgyôr, and Bükkaranyos). The reasons for the increase are unique and special in all three cases: Kistokaj profits from the proximity of the southern industrial park of Miskolc, while Kisgyőr and Bükkaranyos have become increasingly popular suburbs due to their favourable potentials of nature and landscape.

Table 4. The population of the settlements of the Miskolc agglomeration and suburbia (1990-2015)

\begin{tabular}{lccccc}
\hline \multicolumn{1}{c}{ Settlements } & $\mathbf{1 9 9 0}$ & $\mathbf{2 0 0 1}$ & $\mathbf{2 0 0 5}$ & $\mathbf{2 0 1 1}$ & $\mathbf{2 0 1 5}$ \\
\hline Miskolc & $\mathbf{1 9 6 , 4 4 2}$ & $\mathbf{1 8 4 , 1 2 5}$ & $\mathbf{1 7 5 , 0 5 9}$ & $\mathbf{1 6 7 , 7 5 4}$ & $\mathbf{1 5 9 , 5 5 4}$ \\
\hline Miskolc aggl. & $\mathbf{9 2 , 7 1 9}$ & $\mathbf{9 7 , 4 5 1}$ & $\mathbf{9 6 , 4 7 1}$ & $\mathbf{9 4 , 2 1 2}$ & $\mathbf{9 2 , 3 4 7}$ \\
\hline \multicolumn{7}{c}{ of which the settlements of the } & Miskolc suburbia: & & 5,606 \\
\hline Alsózsolca & 5,723 & 6,044 & 6,191 & 5,766 & 2,387 \\
\hline Arnót & 2,082 & 2,557 & 2,650 & 2,597 & 1,499 \\
\hline Bükkaranyos & 1,122 & 1,393 & 1,490 & 1,448 & 1,179 \\
\hline Bükkszentkereszt & 1,374 & 1,274 & 1,215 & 1,206 & 6,486 \\
\hline Felsőzsolca & 6,939 & 7,027 & 7,220 & 6,613 & 1,677 \\
\hline Kisgyőr & 1,572 & 1,609 & 1,665 & 1,642 & 2,083 \\
\hline Kistokaj & 1,489 & 1,868 & 1,916 & 2,078 & 3,929 \\
\hline Mályi & 3,353 & 4,152 & 4,205 & 4,124 & 4,865 \\
\hline Nyékládháza & 4,432 & 4,906 & 5,008 & 5,023 & 4,764 \\
\hline Onga & 4,042 & 4,761 & 4,915 & 4,858 & 4,111 \\
\hline Szirmabesenyő & 4,836 & 4,729 & 4,581 & 4,438 & $\mathbf{3 8 , 5 8 6}$ \\
\hline Total & $\mathbf{3 6 , 9 6 4}$ & $\mathbf{4 0 , 3 2 0}$ & $\mathbf{4 1 , 0 5 6}$ & $\mathbf{3 9 , 7 9 3}$ &
\end{tabular}


The population of Miskolc decreased by approx. 37 thousand people between 1990 and 2015, which was to a lesser extent due to the aging of the population and to a greater extent to out-migration. The population decline of Miskolc accelerated especially in the 1990s, when the decrease was virtually 12 thousand. The massive out-migration of the 1990s was the cumulative result of a number of urban development processes. Meanwhile, the population of the agglomeration zone around Miskolc only grew by five thousand people between 1990 and 2005 . There were only few settlements in the Miskolc agglomeration where significant population growth occurred (Table 4). Suburbs accounted for $90 \%$ of the population increase; however, the increase was different in the settlements of the agglomeration according to geographical position and environmental conditions as well as to the socio-economic status of settlements.

\section{IV.2. Migratory Trends}

In the course of analysing suburban migratory trends, it is worth mentioning that there is a strong tendency for Hungarian people to own their houses or at least flats, which is a 'natural' drive for migration. On the other hand, there exists another tendency, which decreases migration, namely that owning a house means more ties and less mobility.

In the case of the Miskolc agglomeration, the sole financial source of building or buying homes in the suburbs has been provided by the selling of apartments in blocks of flats, i.e. the Western-European type of residential suburbanization has not been typical.

Table 5. Net migration rates of settlements in the Miskolc agglomeration and suburbia (1990-2011)

\begin{tabular}{|c|c|c|c|c|c|c|c|c|c|}
\hline \multirow[t]{2}{*}{ Settlements } & \multicolumn{2}{|c|}{ 1980-1990 } & \multirow{2}{*}{$\frac{1990}{\text { pop. }^{* * *}}$} & \multicolumn{2}{|c|}{ 1990-2001 } & \multirow{2}{*}{$\frac{2001}{\text { pop. }^{* * *}}$} & \multicolumn{2}{|c|}{ 2001-2011 } & \multirow{2}{*}{$\frac{2011}{\text { pop. }^{* * *}}$} \\
\hline & n. i.* ${ }^{*}$ & migr. * * & & n. i.* ${ }^{*}$ & migr. ${ }^{* *}$ & & n. i. * & migr. ** & \\
\hline Miskolc & 1,487 & $-13,148$ & 196,442 & $-6,785$ & $-5,532$ & 184,125 & $-8,425$ & $-7,946$ & 167,754 \\
\hline Miskolci aggl. & 2,927 & $-1,253$ & 92,719 & 1,058 & $\mathbf{3 , 6 7 4}$ & $\mathbf{9 7 , 4 5 1}$ & $-1,764$ & $-1,475$ & 94,212 \\
\hline \multicolumn{10}{|c|}{ of which the settlements of the suburbia: } \\
\hline Alsózsolca & 308 & -175 & 5,723 & 355 & -34 & 6,044 & 161 & -439 & 5,766 \\
\hline Arnót & 170 & 352 & 2,082 & 107 & 368 & 2,557 & 34 & 6 & $\mathbf{2 , 5 9 7}$ \\
\hline Bükkaranyos & -39 & -10 & 1,122 & 16 & 255 & 1,393 & 30 & 25 & 1,448 \\
\hline Bükkszentkereszt & 21 & -22 & 1,374 & -96 & -4 & 1,274 & -85 & 17 & 1,206 \\
\hline Felsôzsolca & 368 & 446 & 6,939 & 193 & -105 & 7,027 & 58 & -472 & 6,613 \\
\hline Kisgyőr & 7 & -67 & 1,572 & -18 & 55 & 1,609 & -39 & 72 & 1,642 \\
\hline Kistokaj & 39 & 205 & 1,489 & 9 & 370 & 1,868 & -27 & 237 & 2,078 \\
\hline Mályi & 168 & 685 & 3,353 & 4 & 795 & 4,152 & -72 & 44 & 4,124 \\
\hline Nyékládháza & 57 & 185 & 4,432 & -67 & 541 & 4,906 & -204 & 321 & 5,023 \\
\hline Onga & 213 & 213 & 4,042 & 278 & 441 & 4,761 & 58 & 39 & 4,858 \\
\hline
\end{tabular}




\begin{tabular}{|c|c|c|c|c|c|c|c|c|c|}
\hline \multirow[t]{2}{*}{ Settlements } & \multicolumn{2}{|c|}{ 1980-1990 } & \multirow{2}{*}{$\frac{1990}{\text { pop. }^{* * *}}$} & \multicolumn{2}{|c|}{ 1990-2001 } & \multirow{2}{*}{$\frac{2001}{\text { pop. }^{* * *}}$} & \multicolumn{2}{|c|}{ 2001-2011 } & \multirow{2}{*}{$\frac{2011}{\text { pop. }^{* * *}}$} \\
\hline & n. i. ${ }^{*}$ & migr. ${ }^{* *}$ & & n. i. ${ }^{*}$ & migr. * * & & n. i. ${ }^{*}$ & migr. * * & \\
\hline Szirmabesenyő & 144 & -77 & 4,836 & -123 & 16 & 4,729 & -238 & -53 & 4,438 \\
\hline Total & 1,456 & 1,735 & 36,964 & 658 & 2,698 & 40,320 & -324 & -203 & 39,793 \\
\hline
\end{tabular}

Regarding migratory processes, the most important two decades of suburbanization were between 1990 and 2011, when three-quarters of the outmigration took place. Between 1990 and 2005, out-migration from Miskolc grew faster than in any other periods in the past; however, only one-third of this migratory process headed towards the Miskolc agglomeration (Table 5). The change in the tendencies of the decade between 1980 and 1990 is shown by the fact that besides the negative net migration rate natural population decline also became characteristic - as a result, the population decline of Miskolc accelerated. One of the results of migratory processes, one of the most important cornerstones of suburbanization is that during the examined two decades all suburbs except for Alsó- and Felsőzsolca had positive net migration rates. The role of six settlements (Arnót, Mályi, Kistokaj, Nyékládháza, Onga, and Bükkaranyos) was outstanding since they accounted for $90 \%$ of the migratory gain of the agglomeration. From 2005 , the positive net migration rate decreased drastically, which was due to the fact that the suburbanization process ground to a halt. Temporary out-migration from Miskolc declined, while temporary in-migration significantly increased.

Deindustrialization and long-lasting depression of the industry coupled with the loss of hundreds of jobs contributed to the former population decline of Miskolc as well as to the social restructuring of the surrounding areas. Lowerstatus layers of society were gradually forced to relocate in less favourable parts of the city or to low-status surrounding settlements. Due to the cumulative results of the above factors, the population of Miskolc decreased by almost 30 thousand people during the two decades between 1990 and 2011. The net migration rate of the city was negative both with respect to the agglomeration and to the suburbia. Between 1995 and 2005, approx. 36 thousand people moved out of Miskolc permanently, while approx. 25 thousand moved into the city. $80 \%$ of those who moved out of Miskolc remained in Borsod-Abaúj-Zemplén County (KSH 2006). However, due to the prolonged socio-economic crisis, out-migration from Miskolc has been continuous ever since.

However, migration towards the Miskolc agglomeration and the suburbia was less dynamic than what could have been expected from demographics. This is partly due to the fact that part of this suburban-type migration remained within the city, i.e. people moving did not cross the administrative borders of Miskolc. There were approx. 5-6 thousand cases of pure residential suburbanization between 1990 and 2001, i.e. when someone moved from the city centre to the 
suburbia. Overall, according to the analysis of migration trends between 1990 and 2011, it can be stated that approx. 6-8 thousand people moved to the suburbia, which cannot be regarded as a massive process (Table 5).

\section{IV.3. Changes in the Demographic and Social Composition}

The past decades of ongoing suburbanization in the Miskolc agglomeration has also changed the social, economic, and land-use characteristics of the surrounding, once rural settlements. Since 1990, two major socio-spatial processes have been observed in the Miskolc agglomeration. On the one hand, the occurrence and general strengthening of the wealthier middle class and, on the other hand, the increasing settlement-level differentiation of the lower status layers of society. One of the results of this process is that by now a contiguous eastern slum zone with marked presence of the ethnic minority (the Romani) has appeared in the Miskolc agglomeration. These trends are well represented in statistics (e.g. housing construction, comfort of dwellings, employment rate, unemployment rate, etc.), of which this study analyses three indicators (age structure, percentage of the population with tertiary education, and tax base of personal income tax) that show the strongest correlation with the above mentioned processes.

\section{IV.3.1. Changes in the Age Structure}

Research results regarding the Budapest agglomeration (e.g. Dövényi-Kovács, 1999 Barta-Beluszky 1999, etc.) have shown that in the middle of the 1990s young couples in their thirties and forties with small children were overrepresented among people moving to suburbs, and this was also true of people with a degree. This was also characteristic of the Miskolc agglomeration; however, the once young generation who had moved to suburbs has now become middle-aged and some of them are already pensioners. This makes the leaders of suburban settlements face new challenges, who have to adapt to the altered needs of local residents. The aging of the population is a general tendency in Hungary, although this process affects Miskolc and its agglomeration differently (Table 6).

Table 6. Age structure of Miskolc and the agglomeration (1990, 2011)

\begin{tabular}{|c|c|c|c|c|c|c|c|}
\hline \multirow[t]{2}{*}{ Settlements } & \multirow[t]{2}{*}{ unit } & \multicolumn{3}{|c|}{1990} & \multicolumn{3}{|c|}{2011} \\
\hline & & 0-14 & 15-59 & $60-x$ & 0-14 & 15-59 & 60-x \\
\hline \multirow{2}{*}{ Miskolc } & people & 40,853 & 122,925 & 32,664 & 2,2831 & 104,101 & 40,822 \\
\hline & $\%$ & 20.8 & 62.6 & 16.6 & 13.6 & $\begin{array}{r}62.1 \\
\end{array}$ & 24.3 \\
\hline \multirow{2}{*}{$\begin{array}{l}\text { Miskolc } \\
\text { agglomeration }\end{array}$} & people & 21,811 & 56,941 & 13,967 & 15,688 & 59,030 & 19,494 \\
\hline & $\%$ & 23.5 & 61.4 & 15.1 & 16.6 & 62.7 & 20.7 \\
\hline
\end{tabular}




\begin{tabular}{|c|c|c|c|c|c|c|c|}
\hline \multirow[t]{2}{*}{ Settlements } & \multirow[t]{2}{*}{ unit } & \multicolumn{3}{|c|}{1990} & \multicolumn{3}{|c|}{2011} \\
\hline & & 0-14 & 15-59 & $60-x$ & 0-14 & 15-59 & $60-x$ \\
\hline Alsózsolca & $\%$ & 25.1 & 61.6 & 13.3 & 20.9 & 60.5 & 18.6 \\
\hline Arnót & $\%$ & 28.5 & 61.0 & 10.5 & 17.1 & 65.2 & 17.8 \\
\hline Bükkaranyos & $\%$ & 21.8 & 59.0 & 19.2 & 18.4 & 63.6 & 18.0 \\
\hline Bükkszentkereszt & $\%$ & 21.8 & 62.4 & 15.8 & 11.6 & 63.3 & 25.1 \\
\hline Felsőzsolca & $\%$ & 24.1 & 62.9 & 13.0 & 17.0 & 61.4 & 21.6 \\
\hline Kisgyőr & $\%$ & 22.3 & 57.6 & 20.1 & 18.1 & 62.0 & 19.9 \\
\hline Kistokaj & $\%$ & 25.4 & 61.5 & 13.1 & 17.9 & 66.7 & 15.3 \\
\hline Mályi & $\%$ & 26.7 & 62.5 & 10.8 & 12.9 & 67.4 & 19.7 \\
\hline Nyékládháza & $\%$ & 22.4 & 62.5 & 15.1 & 13.6 & 60.8 & 25.6 \\
\hline Onga & $\%$ & 25.1 & 60.9 & 14.0 & 19.6 & 63.7 & 16.8 \\
\hline Szirmabesenyő & $\%$ & 21.0 & 64.0 & 15.0 & 11.9 & 64.2 & 23.9 \\
\hline \multirow{2}{*}{$\begin{array}{l}\text { Miskolc } \\
\text { suburbia }\end{array}$} & people & $\mathbf{8 , 8 9 9}$ & 22,923 & 5,142 & 6,545 & 25,106 & 8,142 \\
\hline & $\%$ & 24.0 & 62.0 & 14.0 & 16.4 & 63.1 & 20.5 \\
\hline
\end{tabular}

Source: HCSO Statistical Yearbooks of Borsod-Abaúj-Zemplén County

During the two decades between 1990 and 2011, the values of the aging index fundamentally changed in Miskolc and in the agglomeration. The proportion of the $0-14$ age-group in 2011 was only $13.6 \%$, which is $7.2 \%$ less than in 1990, and the decrease was just slightly smaller in the 35 settlements of the agglomeration. However, there are great differences among suburban settlements. Besides the halving of the 0-14 age-group (e.g. Szirmabesenyő, Mályi, Bükkszentkereszt, etc.), five settlements preserved a youngish age structure (Table 6). In the case of four out of these five settlements (Alsózsolca, Arnót, Bükkaranyos, and Onga), besides suburban processes, the higher percentage of the Romani also contributed to the relatively favourable age structure. In the case of Kistokaj, however, this is not the case since it is a typical suburban settlement whose population increased by $25 \%$ between 1990 and 2005. Young generations (between 30 and 40 years) moved to the settlement, and the majority of them are still active; so, the aging of the population is not or hardly detectable.

\section{IV.3.2. Percentage of the Population with Tertiary Education}

Regarding the level of education, the percentage of the population with tertiary education in the 25-X age-group indicates the differences of suburbanization at the level of settlements. The percentage of the population with tertiary education in Miskolc was $23.7 \%$ in 2011, while in 9 settlements of the agglomeration this figure was between the rate of Miskolc and the county average (14.2\%). However, examination of the percentage of the population with tertiary education shows significant geographical differences at the level of settlements (Map 2). In 2011, the percentage of the population with tertiary education was higher than the average of the suburbia (18.2\%) in several settlements (e.g. Kistokaj (23.1\%), Mályi 
(22.5\%), Felsőzsolca (19.7\%), Arnót (19.5\%), and Nyékládháza (18.9\%), etc.). The significant geographical differences in the percentage of the population with tertiary education are partly due to differences in the social status and residential preferences of people moving out of Miskolc, i.e. these figures indirectly show the group of settlements which has been more strongly affected by suburbanization.

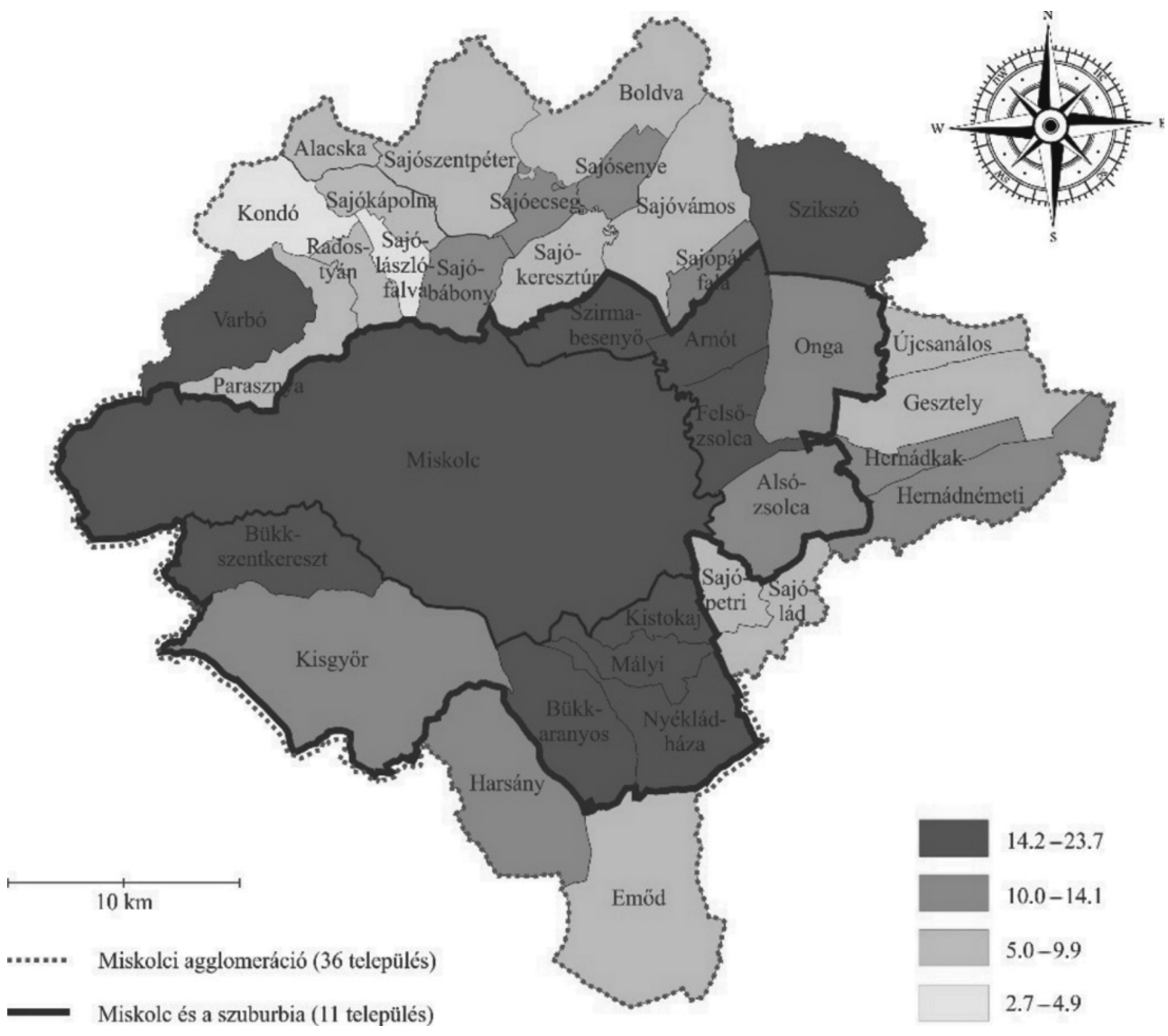

Source: Edited by the author based on HCSO data Map 2. Percentage of the population with tertiary education in the 25-X age-group (2011)

In 15 settlements of the Miskolc agglomeration, the percentage of the population with tertiary education is between 5 and $10 \%$. The percentage of the population with tertiary education is especially small in settlements characterized by peripheral location, poor accessibility, aging population structure, high unemployment rate, and high percentage of the Romani. 


\section{IV.3.3. Differences in the per Capita Tax Base of Personal Income Tax}

The annual value of the per capita tax base of personal income tax reflects the socio-economic level of the development of settlements as well as the geographical disparities among the settlements of the Miskolc agglomeration. In addition, this figure also shows the heterogeneity of the social groups that are involved in residential suburbanization. Due to residential suburbanization, the value of the per capita tax base of personal income tax in the settlements of the Miskolc suburbia is above the county average (Map 3).

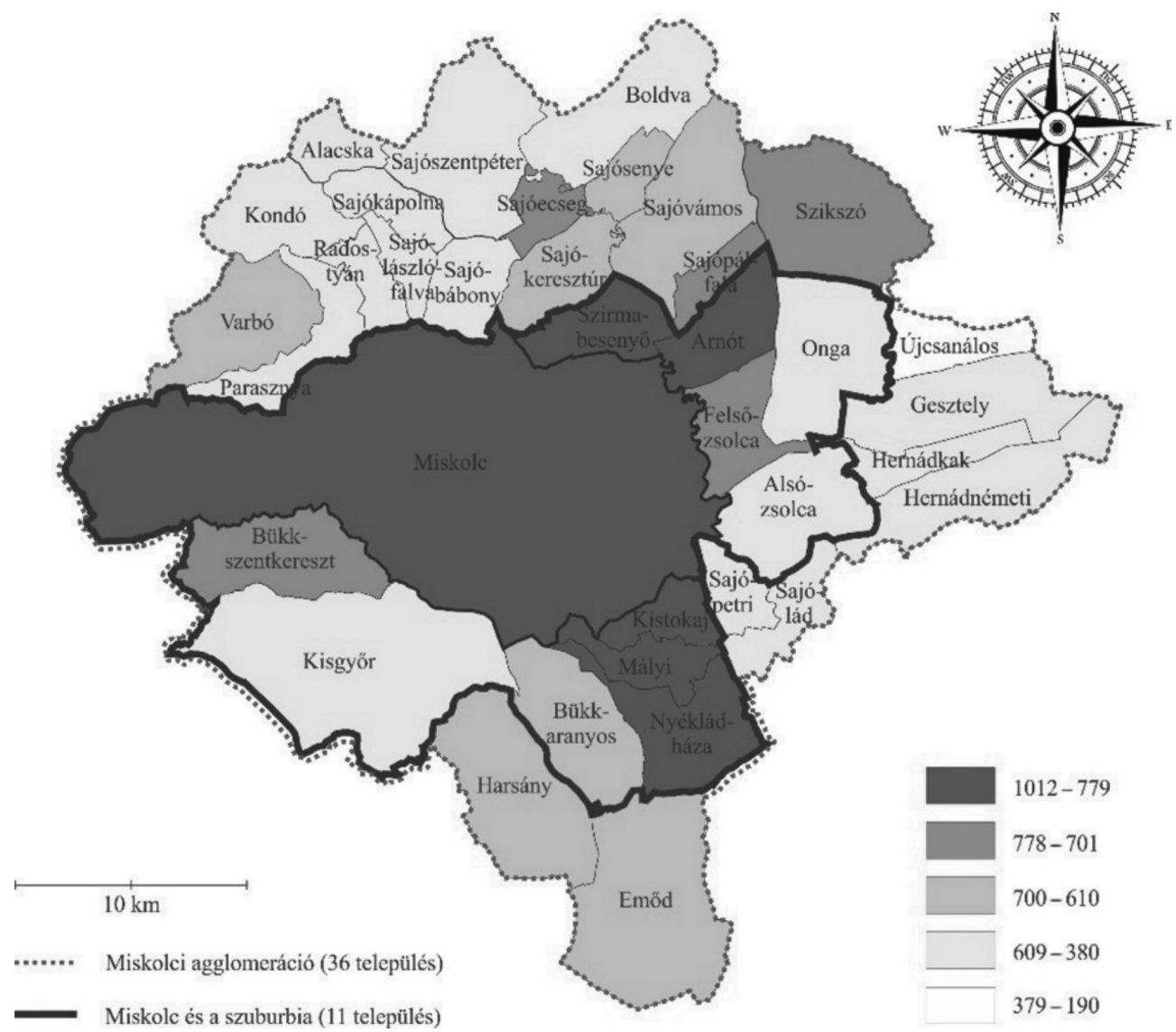

Source: edited by the author based on HCSO data Map 3. Per capita tax base of personal income tax (2011)

The most popular suburban settlements have the highest values, while the lowest figures are characteristic of the eastern suburban settlements where lower educated and lower income groups are concentrated. The value of tax base of 
personal income tax per tax payers and per capita was the highest in Kistokaj (1,012,000 forints) and the lowest in Köröm (190,000 forints). The values of only six settlements were higher than that of Miskolc (779,000 forints per capita), and only five more settlements reached $90 \%$ of the value of the core city. Those settlements (9 pieces) where the value of the tax base of personal income tax was between 75 and $90 \%$ of the value of Miskolc were grouped into a third category, while in the remaining 21 settlements the value of tax base of personal income tax was below $75 \%$ of that of Miskolc (Map 3).

So far the characteristics of suburban processes taking place in the Miskolc agglomeration have been analysed through statistics. On the basis of this analysis, it can be concluded that settlements showing suburban characteristics within the Miskolc agglomeration are not homogenous: different zones of the agglomeration are characterized by different structures. The maps shown above represent well that the status of the people who moved to the southern and western sectors of the Miskolc suburbia has been higher than that of the local residents. On the other hand, lower-status people have moved to the eastern and north-eastern parts of the Miskolc suburbia. By now, the villages and towns (e.g. Onga, Alsóand Felsőzsolca, etc.) of the eastern parts of the suburbia around Miskolc, where low status in-migrants settled down, are struggling with serious socio-economic problems (e.g. increasing out-migration, disappointment of the suburban generation, etc.) the roots of which should be explored by questionnaire surveys.

\section{Summary}

The historical development of the socio-economic, infrastructural, and environmental effects of the agglomerating process in the region of Miskolc has remained an unexplored area even today. No thorough investigation of the specific factors of the agglomerating process around Miskolc as well as the exact identification of the horizontal extension of these factors have been carried out. The economic crisis, the general economic difficulties of Hungary, and the signs of crisis present in the Miskolc agglomeration too have changed the attitudes of settlements towards agglomerating and suburbanizing processes. As a result, former policies supporting extensive development are being replaced by more intensive settlement development ideas that aim for a more efficient stabilization of the population and exploitation of the local resources. These changes also affect the suburbanizing processes in the Miskolc agglomeration, i.e. the intensity of suburbanization is decreasing. The suburbs of Miskolc have become more and more fragmented and polarized in terms of the society and economy. The geographical separation of high- and low-status suburbs proves the everincreasing segregation within the metropolitan area. 


\section{References}

BAJMÓCY, Péter. 1999. A szuburbanizáció sajátosságai Pécs környékén [Characteristics of Suburbanization around Pécs]. Földrajzi Értesítő 1-2: 127-138.

BARTA, Györgyi-BELUSZKY, Pál. 1999. Társadalmi-gazdasági átalakulás a Budapesti agglomerációban [Socio-Economic Transformation in the Budapest Agglomeration]. Regionális Kutatási Alapítvány.

CSANÁDY, Gábor-CSIZMADY, Adrienne-KOCSIS, János Balázs-KŐSZEGHY, Lea-TOMAY, Kyra. 2010. Város-Tervezó-Társadalom [City-Planner-Society]. Budapest: Sík Kiadó.

DÖVÉNYI, Zoltán-KOVÁCS, Zoltán. 1999. A szuburbanizáció térbenitársadalmi jellemzői Budapest környékén [Socio-Spatial Characteristics of Suburbanization around Budapest]. Földrajzi Értesító XLVIII(1-2): 33-57.

ENYEDI, György. 1984. Az urbanizációs ciklus és a magyar településhálózat átalakulása [The Cycle of Urbanization and the Transformation of the Hungarian Settlement Network]. Budapest: Akadémiai Kiadó.

FEJES, László-SZABÓ, Zsuzsánna. 2003. A nagyvárosok belsó tagozódása: Miskolc [Urban Structure of Cities: Miskolc]. KSH Borsod-Abaúj-Zemplén Megyei Igazgatósága.

FÓRIZS, Margit. 1967. Városok körül kialakult településegyüttesek Magyarországon [Settlement Groups around Cities in Hungary]. Demográfia 1967(1): 55-70.

GNARR, E.-KNEEBOONE, Elizabeth. 2010. The Suburbanization of Poverty. Trends in Metropolitan America. Brooking Research Paper. http://www. brookings.edu/research/papers/2010/01/20-poverty-kneebone.

HARDI, Tamás. 2012. Győr, Pécs és Miskolc agglomerációja a vidéki szuburbanizációban [Agglomerations of Győr, Pécs, and Miskolc in the Rural Suburbanization]. In: Somlyódyné Pfeil, Edit (ed.), Az agglomerációk intézményesítésének sajátos kérdései [Special Questions of Institutionalizing Agglomerations]. Pécs. 15-41.

KÓKAI, Sándor. 2006. Adalékok a nyíregyházi településegyüttes szuburbanizációs folyamatainak vizsgálatához [Suburbanizing Processes in the Nyíregyháza Settlement Group Revisited]. In: Csapó, Tamás-Kocsis, Zsolt (eds), Agglomerációk és szuburbanizálódás Magyarországon [Agglomerations and Suburbanization in Hungary]. Szombathely: Savaria University Press. 168-188.

KŐSZEGFALVI, György. 1979. Az agglomerálódási folyamat kritériumai. Az agglomerációk szerkezetének néhány jellemző sajátossága [Criteria for the Agglomerating Process. A Few Characteristic Features of the Structure of Agglomerations]. In: Pálné Kovács, Ilona-Rechnitzer, János (eds), $A z$ agglomeráció-kutatás módszertani kérdései [Methodological Issues of Researching Agglomerations]. Pécs: MTA DTI. 67-71. 
1999. Nagyvárosaink [Our Cities]. Területi Statisztika 2 39(1): 24-42.

2009. Törekvések a magyarországi településrendszer tudatos fejlesztésére [Ambitions to Consciously Develop the Settlement Network of Hungary]. Területi Statisztika: 571-584.

2010. Településrendszerünk strukturális változásának tendenciái [Tendencies of Structural Changes in the Hungarian Settlement Network]. Területi Statisztika 2010(3): 268-278.

KOVÁCS, Tibor (ed.). 2003. Miskolci agglomeráció [Miskolc Agglomeration]. Miskolc: HCSO.

KOVÁCS, Tibor-TÓTH, Géza. 2003. Agglomerációk, településegyüttesek a magyar település-rendszerben [Agglomerations, Settlement Groups in the Hungarian Settlement Network]. Területi Statisztika 6 43(4): 387-391.

KRISTÓF, Andrea. 2014. A miskolci agglomeráció kisvárosai [The Small Towns of the Miskolc Agglomeration]. Településföldrajzi Tanulmányok 3(1): 81-96.

KRISTÓF, Andrea-KÓKAI, Sándor. 2015. Adalékok a miskolci szuburbia lehatárolásához [Identification of the Miskolc Suburbia Revisited]. Településföldrajzi Tanulmányok 2015(special issue).

LŐCSEI, Hajnalka. 2004. A vidéki városi agglomerációk fejlődési pályája [The Development Path of Rural Agglomerations]. Múhelytanulmányok [Working Papers]. Budapest: MT.DP. 2004/24, MTA Közgazdaságtudományi Intézet.

LUKÁCS, Jánosné-PERGER, Frigyesné. 1975. Egy változat az agglomeráció jelenlétének és körének kimutatására Miskolc és környékének adatai alapján [A Possible Way to Detect the Presence and Extension of the Agglomeration on the Basis of the Data on Miskolc and its Surrounding Areas]. Területi Statisztika 1: 24-31.

MERLIN, Pierre. 2009. L'exode urbain. La documentation Francaise. Paris. NAGY, Gábor-TÍMÁR, Judit. 2010. Városrégiók a hazai térkutatásokban [Urban Regions in Spatial Research in Hungary]. http://www.varoster.hu/docs/ Városrégiók a hazai térkutatásokban.pdf (Accessed on: 20.12.2015).

PERCZEL, Károly. 1964. A regionális tervezés és városrendezés fejlódése Magyarországon 1945-től napjainkig [The Development of Regional and Urban Planning in Hungary from 1945 to the Present]. Városépítés 1964(1): 4-7.

1981. Az urbanizáció minőségi tényezői [The Qualitative Factors of Urbanization]. Településfejlesztés 1981(1-2): 93-100.

SÜLI-ZAKAR, István. 1985. Az agglomerálódás népességföldrajzi vonatkozásai a Borsodi Iparvidéken [Social Geographical Aspects of Agglomerating in the Borsod Industrial Region]. In: Borsodi Földrajzi Évkönyv. Miskolc. 47-66. 1989. Agglomerationsprozesse und ihre fragezeichen in dem Borsoder Industriegebiet. Acta Geographica Debrecina XXIV-XXV: 199-211. 
SZÁNTÓ, Zsuzsa. 1979. Funkcionálisan együttélő településcsoportok [Functionally Coexisting Settlement Groups]. Településtudományi Közlemények 1: 41-60.

SCHUCHMANN, Júlia. 2008. Városiasodó községek és nagyközségek az agglomeráció peremén [Urbanizing Villages and Large Villages at the Verge of the Agglomeration]. In: Csapó, Tamás-Kocsis, Zsolt: Nagyközségek és kisvárosok a térben [Large Villages and Small Towns in Space]. IV. Településföldrajzi Konferencia. Szombathely: Savaria University Press. 293-305.

SCHUCHMANN, Júlia. 2013. Lakóhelyi szuburbanizációs folyamatok a Budapesti agglomerációban [Residential Suburbanizing Processes in the Budapest Agglomeration]. PhD thesis (manuscript).

THE ATTRACTIVENESS of European Regions and Cities for Residents and Visitors, ESPON 2012. http://www.espon.eu/export/sites/default/Documents/ Projects/AppliedResearch/ATTREG/FR_20130123/01_Sci entific_report_REV. pdf.

TIMÁR, Judit. 2006. Az agglomerálódástól a szuburbanizációig: „Tértermelés” a posztszocialista Magyarországon [From Agglomerating to Suburbanization: 'Production of Space' in Post-Socialist Hungary]. In: Csapó, Tamás-Kocsis, Zsolt (eds), Agglomerációk és szuburbanizálódás Magyarországon [Agglomerations and Suburbanization in Hungary]. Szombathely: Savaria University Press. 35-51. TÓTH, József. 1985. Az urbanizációs folyamat néhány elméleti kérdése, különös tekintettel az Alföldre [Some Theoretical Questions of the Urbanizing Process with Special Regard to the Hungarian Great Plain]. Alföldi Tanulmányok IX: 123-138. Békéscsaba.

1988. Urbanizáció az Alföldön [Urbanization in the Hungarian Great Plain]. HAS Doctoral Dissertation.

2006. Az agglomerálódás stádiumai [Stages of Agglomerating]. In:Csapó, TamásKocsis, Zsolt (eds), Agglomerálódás és szuburbanizációk Magyarországon [Agglomerations and Suburbanization in Hungary]. Szombathely. 6-14.

VALÉR, Éva. 2009. A magyarországi agglomerálódás folyamatának alakulása [Evolution of the Hungarian Agglomerating Process]. OTKA, Closing report. (Downloaded on: 20 December 2015).

MISKOLC ITS - III. Helyzetértékelés. 2013. [Miskolc Integrated Settlement Strategy - III. Situation Analysis]. Miskolc.

VÁTI Kht. 2001. Miskolc hipotetikus agglomerációjának lehatárolása [Identification of the Hypothetical Agglomeration of Miskolc]. Budapest: VÁTI Kht. 